\title{
Response of suckling beef cows to multiple, low-dose injections of Gn-RH with or without progesterone pretreatment
}

\author{
S. Edwards*, J. F. Roche† and G. D. Niswender $\ddagger$ \\ The Agricultural Institute, Grange, Dunsany, Co. Meath, Ireland, and $¥$ Department of Physiology \\ and Biophysics, Colorado State University, Fort Collins, Colorado 80523, U.S.A.
}

\begin{abstract}
Summary. Treatment of 97 suckling beef cows at about 30 days post partum with doses of $0 \cdot 25,0.5,1 \cdot 0,2 \cdot 5,3 \cdot 0$, or $5.0 \mu \mathrm{g} \mathrm{Gn-RH} /$ pulse for period of $2-4$ days at $1 \cdot \mathrm{h}$ or $2-\mathrm{h}$ intervals in three different experiments did not increase the number of cows ovulating when compared to untreated controls. Treatment with 0.25 or $0.5 \mu \mathrm{g} \mathrm{Gn}-\mathrm{RH} / \mathrm{pulse}$ resulted in little or no LH release, whereas higher doses gave discernible LH releases after each $\mathrm{Gn}-\mathrm{RH}$ pulse. Pretreatment with progesterone did not affect the ovulatory or LH responses.

These data indicate that pulsatile injections of Gn-RH, at the dose levels and frequencies used, cannot reactivate ovarian cyclicity in a majority of cows. We suggest that the degree of follicular development at the time of treatment is a major factor determining the ovulatory response to such pulsatile Gn-RH regimens.
\end{abstract}

\section{Introduction}

It has been reported that cows suckling calves exhibit a longer post-partum interval before returning to cyclic ovarian activity than do non-suckling cows or milked dairy cows (Wiltbank \& Cook, 1958; Casida et al., 1968; Oxenreider, 1968). The length of this post-partum anoestrous period can also be affected by a number of factors, including breed and plane of nutrition (Inskeep \& Lishman, 1979). In an attempt to understand and overcome the inhibitory effects of suckling on reproduction, several comparative endocrine studies have been made on suckling and milked cows. Carruthers \& Hafs (1980) showed that a pulsatile pattern of LH release develops 10-15 days after calving in dairy cows but is significantly delayed in dairy cows suckling calves. Confirmation of the later development of a pulsatile $\mathrm{LH}$ release pattern in the suckled beef cow has been provided by Peters, Lamming \& Fisher (1981), suggesting that the pulsatile mode of LH secretion may be an important factor in stimulating follicular growth early in the post-partum period. To test this hypothesis requires the induction of ovarian cyclicity in anoestrous cows by pulsatile injections of Gn-RH.

Riley, Peters \& Lamming (1981) and Walters et al. (1982) have shown that such regimens can be effective in inducing ovulation and initiating ovarian cyclicity in suckling cows. Such treatments can also induce ovulation in the seasonally anoestrous ewe (McNatty, Ball, Gibb, Hudson \& Thurley, 1982; McLeod, Haresign \& Lamming, 1982a), hypophysectomized and prepubertal

* Present address: University of Missouri-Columbia, 159 Animal Science Research Center, Columbia, Missouri 65211, U.S.A.

† Present address: Veterinary Field Station, Ballycoolin Road, Finglas, Dublin 11, Ireland. 
rhesus monkey (Knobil, 1981) and amenorrhoeic women (Leyendecker \& Wildt, 1983). The following series of experiments attempted to assess the effects of Gn-RH dosage and season of treatment on the pattern of LH secretion in beef cows suckling calves.

\section{Materials and Methods}

Experiment 1 . In this preliminary study, 23 Hereford $\times$ Friesian primiparous cows calving between 6 September and 1 October 1979 (autumn calvers) were used. Each cow was run at pasture of high quality and was suckling a single calf. At 16-40 days post partum (mean \pm s.e.m. $=27.5 \pm 1.4$ days) each heifer was (i) left untreated (controls), or treated with 2.5 or $5 \mu \mathrm{g} \mathrm{Gn-RH}$ (Hoechst Ltd, Dublin, Ireland) in sterile saline $(0.9 \% \mathrm{w} / \mathrm{v} \mathrm{NaCl})$ i.v. at 2 -h intervals for $72 \mathrm{~h}$. Blood samples (10 $\mathrm{ml}$ ) were taken on Days -4 and -1 before pulsing began (Day 0 ) and at 3-day intervals for 3 weeks after pulsing ended and assayed for progesterone. The ovaries of all cows were examined at laparoscopy 4 days after pulsing ended.

Experiment 2. For a more detailed assessment of gonadotrophin responses to pulsatile Gn-RH treatment, 48 Hereford $\times$ Friesian second lactation cows which calved between 10 April and 13 June 1980 (spring calvers) were used. After calving, all cows were turned out to good quality permanent grass pasture and were rotated among paddocks to ensure adequate pasture at all times. Each cow was suckling a single calf and at 25-60 days (mean $32.7 \pm 0.8$ days) after calving was allocated to one of the following treatments: Group 1, untreated controls; hourly i.v. injections of $1 \mu \mathrm{g} \mathrm{Gn-RH} \mathrm{(Group} \mathrm{2),} \mathrm{or} 3 \mu \mathrm{g} \mathrm{Gn-RH} \mathrm{(Group} \mathrm{3)} \mathrm{for} 94 \mathrm{~h}$; or (Group 4) a progesterone-releasing intravaginal device (PRID) was inserted and remained in place for 7 days beginning at approximately Day 25 post partum. An i.m. injection of a synthetic analogue of prostaglandin (PG) F- $2 \alpha$ (Estrumate: ICI Ltd, Dublin, Ireland) was given 6 days after PRID insertion and the PRIDs were withdrawn on Day 7. The animals then received hourly i.v. injections of $1 \mu \mathrm{g} \mathrm{Gn}-\mathrm{RH}$ for $94 \mathrm{~h}$. The Gn-RH, in all cases, was injected into the jugular vein via an indwelling catheter and flushed with $2 \mathrm{ml}$ saline immediately after injection.

Blood samples were withdrawn via the same jugular catheter at 20 -min intervals from all animals for $4 \mathrm{~h}$ before the beginning of $\mathrm{Gn}-\mathrm{RH}$ treatments (=time 0 ) and then from half of the animals in each group at 0-4 h, 20-24 h, 44-48 h, 68-72 h and 90-94 h. In addition, samples for LH measurements were withdrawn every $2 \mathrm{~h}$ beginning at time 0 from all animals, except 3 cows in Group 4. The ovaries of all cows were examined at laparoscopy 7-8 days after pulsing ended. A vasectomized bull with a chin-ball mating device was run with the cows after the end of Gn-RH treatment and cows were checked twice daily to detect oestrus.

Experiment 3. In this experiment 26 Hereford $\times$ Friesian cows calving between 15 September and 9 October 1980 (autumn calvers) were used to study the effects of different doses of Gn-RH. The cows were run at pasture and each cow was suckling a single calf. At 25-38 days (31.2 \pm 0.7 days) after calving the cows were left as untreated controls (Group 1), or given hourly i.v. injections of $0.25 \mu \mathrm{g} \mathrm{Gn}-\mathrm{RH}$ (Group 2), or $0.5 \mu \mathrm{g} \mathrm{Gn}-\mathrm{RH}$ (Group 3) for $48 \mathrm{~h}$. The Gn-RH was administered as described in Exp. 2.

Blood samples were withdrawn via the same jugular catheters at 20 -min intervals from all cows for the $4 \mathrm{~h}$ before the onset of Gn-RH pulsing (=time 0 ) and thereafter from half of the animals at $0-4 \mathrm{~h}, 20-24 \mathrm{~h}$ and $44-48 \mathrm{~h}$. In addition, all cows were bled at 2-h intervals for $48 \mathrm{~h}$ beginning at time 0 and these samples were assayed for LH. The ovaries of all cows were examined at laparoscopy 6-8 days after the end of Gn-RH treatment.

Hormone assays. Blood samples were centrifuged immediately and the plasma was kept at $-20^{\circ} \mathrm{C}$ until assay. Progesterone in plasma was assayed by the method of Gosling, Parker \& Fottrell (1975). The antiserum was obtained from Dr L. Edquist and had low cross-reactivity with other steroids. The inter- and intra-assay coefficients of variation $(\mathrm{CVs})$ were $11.7 \%$ and $8.5 \%$ respectively. The minimum detectable dose using $100 \mu \mathrm{l}$ plasma was $0 \cdot 18 \mathrm{ng} / \mathrm{ml}$. Estimates of the 
recovery of steroid from plasma during extraction yielded a figure of $92.0 \pm 5.8 \%$ and all values were corrected for these losses. LH was assayed by the method of Niswender, Reichert, Midgley \& Nalbandov (1969) with the following modifications. Bovine LH (LER-1716-2) was iodinated by a modification of the chloramine-T method of Greenwood, Hunter \& Glover (1963) in which $2 \mu \mathrm{g}$ purified hormone in $20 \mu 10.05 \mathrm{M}$-phosphate buffer were reacted with $1 \mathrm{mCi} \mathrm{Na}^{125} \mathrm{I}$ and $20 \mu \mathrm{g}$ chloramine-T in $10 \mu 10.05 \mathrm{M}$-phosphate buffer for $30 \mathrm{sec}$. The labelled hormone was separated from the mixture by column chromatography on Sephadex G75 and diluted to 15000 c.p.m./100 $\mu 1$ in assay diluent. The assay standard was NIAMDD-bLH-B4 and all values are expressed as ng bLHB4 per ml plasma. The antiserum to ovine LH (GDN No. 15) was used at a working dilution of $1: 60000$ in $1: 400$ normal rabbit serum and the bound fraction was precipitated by adding $200 \mu l$ sheep anti-rabbit gamma-globulin, raised in a ram kept locally, at a dilution of $1: 30$ in phosphatebuffered saline. The inter- and intra-assay CVs for $200 \mu \mathrm{l}$ of a standard cow plasma were $3 \cdot 2 \%$ and $2.6 \%$ respectively and the minimum detectable dose was $0.03 \mathrm{ng} / \mathrm{tube}$.

\section{Results}

\section{Experiment 1}

Pulses of 2.5 or $5.0 \mu \mathrm{g} \mathrm{Gn-RH}$ every $2 \mathrm{~h}$ for $72 \mathrm{~h}$ resulted in ovulation in $1 / 8$ and $0 / 8$ cows respectively while $0 / 7$ controls had ovulated at the same stage. However, $2 / 8$ cows treated with $2.5 \mu \mathrm{g} \mathrm{Gn}-\mathrm{RH} /$ pulse had a rise in plasma concentrations of progesterone after a delay of 8 days. Similarly $1 / 7$ control cows had a rise in plasma progesterone concentrations 14 days after pulsing ended whilst $0 / 8$ cows treated with $5.0 \mu \mathrm{g} \mathrm{Gn}-\mathrm{RH} /$ pulse had a significant rise in progesterone concentration in the 3 weeks after treatment. There was no laparoscopic evidence of stimulation of follicular development in any of the cows.

Table 1. Time of detection of the LH peak, occurrence of a pre-peak rise in LH, and ovulation after lowdose injections of Gn-RH for $94 \mathrm{~h}$ in post-partum beef cows suckling calves (Exp. 2)

\begin{tabular}{|c|c|c|c|c|}
\hline Treatment & Cow No. & $\begin{array}{l}\text { Time of LH } \\
\text { peak }(\mathrm{h})^{*}\end{array}$ & $\begin{array}{l}\text { Pre-peak LH } \\
\text { rise }\end{array}$ & Ovulation \\
\hline Control & 145 & 58 & Yes & Yes \\
\hline $1 \mu \mathrm{g} \mathrm{Gn-RH}$ & $\begin{array}{r}97 \\
138 \\
401 \\
140 \\
314 \\
120 \\
131 \\
111\end{array}$ & $\begin{array}{l}24 \\
56 \\
40 \\
82 \\
60 \\
40 \\
72 \\
66\end{array}$ & $\begin{array}{l}\text { No } \\
\text { Yes } \\
\text { No } \\
\text { No } \\
\text { No } \\
\text { No } \\
\text { Yes } \\
\text { Yes }\end{array}$ & $\begin{array}{l}\text { No } \\
\text { Yes } \\
\text { No } \\
\text { No } \\
\text { Yes } \\
\text { Yes } \\
\text { Yes } \\
\text { Yes }\end{array}$ \\
\hline $3 \mu \mathrm{g} \mathrm{Gn}-\mathrm{RH}$ & $\begin{array}{r}136 \\
99 \\
143 \\
103 \\
94\end{array}$ & $\begin{array}{r}60 \\
4 \\
34 \\
2 \\
28\end{array}$ & $\begin{array}{c}\text { No } \\
\text { Too early to say } \\
\text { Yes } \\
\text { Too early to say } \\
\text { No }\end{array}$ & $\begin{array}{l}\text { No } \\
\text { No } \\
\text { No } \\
\text { No } \\
\text { No }\end{array}$ \\
\hline $\begin{array}{l}\text { PRID + } \\
\quad I \mu \mathrm{g} \mathrm{Gn-RH}\end{array}$ & $\begin{array}{r}403 \\
144 \\
297 \\
152 \\
81\end{array}$ & $\begin{array}{l}22 \\
16 \\
56 \\
90 \\
42\end{array}$ & $\begin{array}{l}\text { No } \\
\text { No } \\
\text { No } \\
\text { No } \\
\text { No }\end{array}$ & $\begin{array}{l}\text { No } \\
\text { No } \\
\text { Yes } \\
\text { Yes } \\
\text { No }\end{array}$ \\
\hline
\end{tabular}

* Time of first injection $=0 \mathrm{~h}$. 


\section{Experiment 2}

Hourly pulses of 1 or $3 \mu \mathrm{g} \mathrm{Gn-RH}$ for $94 \mathrm{~h}$ resulted in $5 / 12$ and $2 / 12$ cows respectively having ovulated at laparoscopy while $4 / 12$ control cows had ovulated at the same stage. Pretreatment with a PRID followed by $1 \mu \mathrm{g} \mathrm{Gn-RH}$ hourly for $94 \mathrm{~h}$ resulted in 3/12 cows ovulating. In the cows treated with 1 or $3 \mu \mathrm{g} \mathrm{Gn}-\mathrm{RH}, 8 / 12$ and 5/12 respectively showed preovulatory LH surges, whereas only $1 /$ 12 control cows did so. In the PRID pretreated group, 5/9 cows showed preovulatory LH surges during sampling. There was no evidence of stimulation of follicular development by Gn-RH at laparoscopy, and treatment did not shorten the interval from calving to first detected oestrus which was $55 \pm 3 \cdot 4,58 \pm 3 \cdot 7,56 \pm 2 \cdot 0$ and $61 \pm 4 \cdot 7$ days respectively for cows in Groups 1 to 4 . Representative 20-min LH profiles obtained from cows in each of the groups are shown in Text-fig. 1. Gn-RH at 1 and $3 \mu \mathrm{g}$ was effective in releasing small pulses of $\mathrm{LH}$ but there was considerable variation in the $\mathrm{LH}$ responses between animals. Pretreatment with progesterone did not reduce this inter-animal variation in response to $\mathrm{Gn}-\mathrm{RH}$. In a majority $(25 / 31$ profiles, $80 \%)$ of the periods before Gn-RH treatment, and in control cows, pulsatile LH releases were evident (Text-fig. 1) but the frequency and amplitude of these LH episodes varied considerably between animals. The type of LH pattern seen before Gn-RH treatment bore no relationship to that seen during treatment (compare Cows 111 and 131, and Cows 136 and 143). The timing of preovulatory-type LH surges in these cows was not synchronized by treatment and occurred between 2 and $88 \mathrm{~h}$ after treatment began (Table 1). Of the cows given Gn-RH pulses, 4 had definite rises in LH before the LH peak and 3 ovulated, while $4 / 12$ cows that exhibited LH peaks but no pre-peak rise in LH had ovulated

(a)
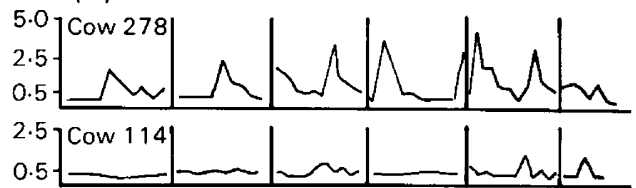

(d)
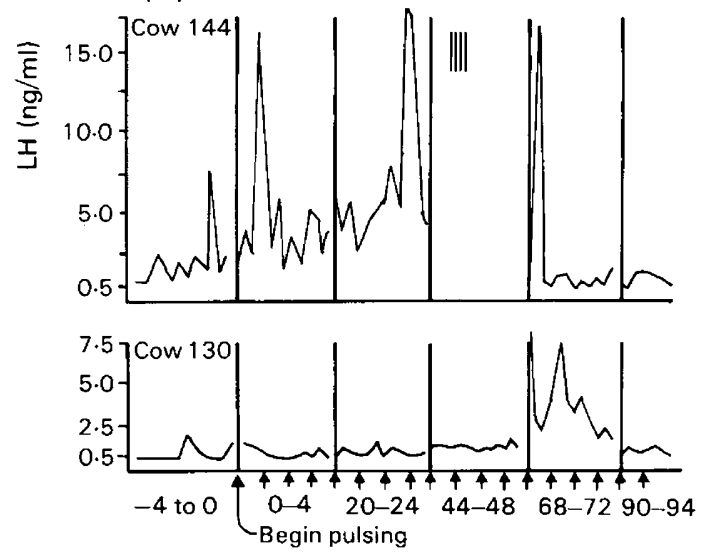

(b)

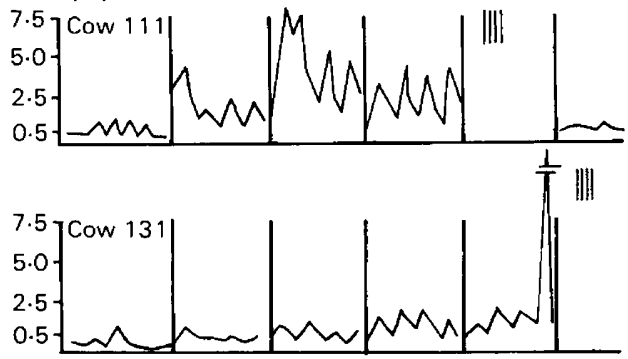

(c)
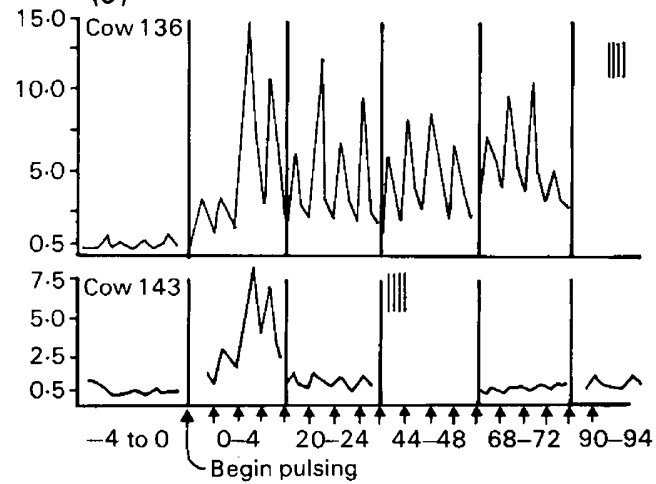

Hours

Text-fig. 1. Representative LH profiles (Exp. 2) from samples taken at 20-min intervals from (a) untreated control cows, (b) cows treated with $1 \mu \mathrm{g} \mathrm{Gn}-\mathrm{RH} / \mathrm{h}$ for $94 \mathrm{~h}$, (c) cows treated with 3 $\mu \mathrm{g} \mathrm{Gn}-\mathrm{RH} / \mathrm{h}$ for $94 \mathrm{~h}$ and (d) cows pretreated with a PRID and then $1 \mu \mathrm{g}$ Gn-RH/h for $94 \mathrm{~h}$ beginning at the time of PRID removal. Vertical arrows indicate individual Gn-RH injections. The four vertical lines indicate the time of the LH surge as indicated by the 2-h samples taken throughout. 
(Table 1). It also appeared that the interval from the start of $\mathrm{Gn}-\mathrm{RH}$ injections to the time of occurrence of the LH peak affected the number of cows which ovulated, because $1 / 9$ cows ovulated when the LH peak occurred within 48 h of the start of the Gn-RH treatment schedule compared to $6 / 9$ ovulating when the LH peak occurred more than $48 \mathrm{~h}$ after the start of treatment.

\section{Experiment 3}

Hourly pulses of 0.25 or $0.5 \mu \mathrm{g} \mathrm{Gn-RH}$ for $48 \mathrm{~h}$ resulted in $0 / 9$ and $1 / 9$ cows respectively ovulating, while $5 / 8$ control cows had ovulated at the same stage. Of these cows, only 1 (given $0 \cdot 5 \mu \mathrm{g}$ Gn-RH) showed preovulatory LH surges during sampling. There was little follicular activity visible in cows at laparoscopy.

Representative 20-min LH profiles are shown in Text-fig. 2; doses of 0.25 or $0.5 \mu \mathrm{g} \mathrm{Gn-RH/}$ pulse were generally less effective in stimulating LH release than the higher doses used in Exp. 2. In addition, fewer of the pretreatment and control profiles showed episodic LH activity (4/12 or $33 \%$ ). The type of LH pattern seen before Gn-RH treatment bore no relationship to that seen during treatment and the one LH surge seen during sampling occurred $16 \mathrm{~h}$ after treatment had begun.

(a)

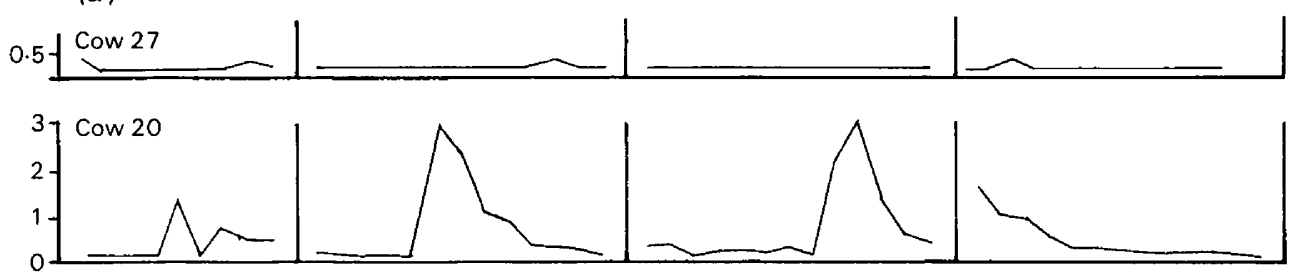

(b)

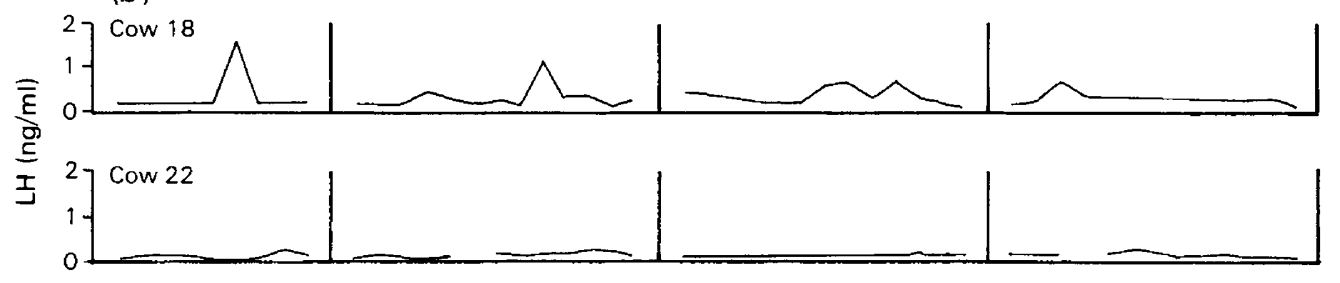

(c)
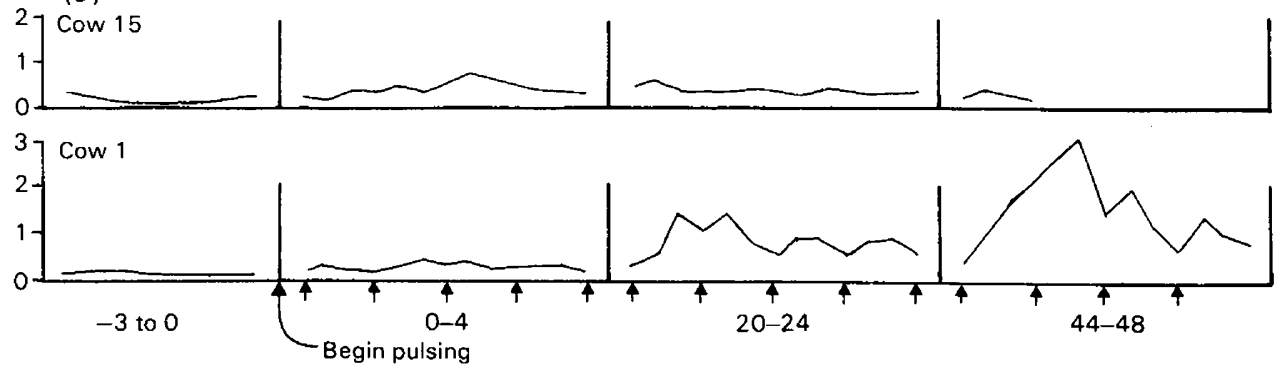

Hours

Text-fig. 2. Representative LH profiles (Exp. 3) from samples taken at 20-min intervals for $4 \mathrm{~h}$ in (a) untreated control cows, (b) cows treated with $0.25 \mu \mathrm{g} \mathrm{Gn}-\mathrm{RH}$ at $1-\mathrm{h}$ intervals for $48 \mathrm{~h}$, and (c) cows treated with $0.5 \mu \mathrm{g}$ Gn-RH at 1-h intervals for $48 \mathrm{~h}$. Vertical arrows indicate individual Gn-RH injections. 


\section{Discussion}

Currently available data suggest that the development of a pulsatile pattern of $\mathrm{LH}$ release may be a major factor influencing the return to cyclic ovarian activity in the post-partum cow (Carruthers \& Hafs, 1980; Peters et al., 1981; Humphrey, Kaltenbach, Dunn, Koritnik \& Niswender, 1983). If this pattern of LH secretion is mimicked by multiple, low-dose Gn-RH injections in anoestrous suckling cows, the resultant ovulatory responses can be as high as $80 \%$ (Riley et al., 1981; Walters et al., 1982).

The ovulatory data from the current experiments, however, using a large number of animals and a range of doses and frequencies of injection, has not resulted in any significant effect of $\mathrm{Gn}$ RH treatment on the number of beef cows ovulating when compared to untreated animals. The reasons for this may be related to the degree of follicular development and maturation at the time of treatment. Suckling cows in anoestrus have been reported to release $\mathrm{LH}$ in a pulsatile fashion at frequencies of $0-0.5$ pulses/h increasing to frequencies of $0.25-1.25$ pulses $/ \mathrm{h}$ several days before first ovulation (Carruthers \& Hafs, 1980; Peters et al., 1981; Riley et al., 1981). Frequencies of 0 1.25 pulses/h were observed in the current experiments with a tendency for the autumn-calving cows to show less pulsatile LH activity than the spring calvers, which may be related to the postpartum intervals seen in such cows (Peters \& Riley, 1982). At the start of the Gn-RH injections the frequency of $\mathrm{LH}$ pulses generally increased to values between 0.5 and 1.0 pulse/h (dependent upon the treatment), with each LH pulse being of generally higher amplitude (except with the 0.25 and $0.5 \mu \mathrm{g}$ doses) than in the pretreatment period. Nevertheless, although the frequency of LH pulses was maintained or increased to a value similar to that seen in the normal follicular phase, the ovulatory responses in these suckling cows remained generally poor. In the present experiments the cows were kept on pasture of very high quality and the plane of nutrition was not felt to be a contributory factor.

During the follicular phase of the oestrous cycle LH pulses are of high frequency and the amplitude varies between 4 and $6 \mathrm{ng} / \mathrm{ml}$ (Rahe, Owens, Fleeger, Newton \& Harms, 1980). A similar change is seen in the period before a return to ovarian activity in the post-partum cow (Carruthers \& Hafs, 1980; Peters et al., 1981). Treatment of suckling cows with multiple injections of $5 \mu \mathrm{g} \mathrm{Gn-}$ RH resulted in LH pulses of similar amplitude to those seen in the follicular phase of the oestrous cycle and good ovulatory responses were obtained (Riley et al., 1981). The concentrations of LH in the plasma of cows in the current experiments injected with 1 or $3 \mu \mathrm{g} \mathrm{Gn-RH} \mathrm{resulted} \mathrm{in} \mathrm{LH} \mathrm{pulses}$ which did not differ appreciably from those previously reported (visual appraisal only) and pretreatment with progesterone did not appear to influence the pituitary response to Gn-RH. This is in agreement with results for anoestrous sheep in which progesterone pretreatment neither influenced the magnitude of LH pulses resulting from multiple Gn-RH injections nor altered the number of sheep which ovulated, although the progesterone pretreatment did synchronize the preovulatory LH surges, and thus ovulation (McLeod et al., 1982a, b). These data suggest that progesterone may act to synchronize follicular growth and produce a group of follicles all at an appropriate stage of development to respond fully to the Gn-RH-induced LH episodes. That this situation does not appear to occur in the suckling cow may be due to differences in the endocrine causes of lactational and seasonal anoestrus or a reflection of inter-species differences in the stimuli/inhibitors for follicular growth.

One major determinant of the pituitary responsiveness to Gn-RH is oestrogen (Padmanabhan, Kesner \& Convey, 1978; Padmanabhan \& Convey, 1978) in that chronic exposure to oestrogen, as occurs during the preovulatory rise on oestradiol, results in a rise in basal or tonic LH secretion coupled to an increase in the pituitary responsiveness to Gn-RH. Of the cows in our studies which showed a preovulatory $\mathrm{LH}$ surge without having a pre-peak rise in the basal concentrations of $\mathrm{LH}$, 4 of 12 had ovulated by the time of laparoscopy. This adds further evidence to the hypothesis that a pre-peak rise in tonic LH secretion is an important factor in whether a cow will ovulate (Roche, Ireland \& Mawhinney, 1981). The presence of an LH surge, in the absence of measurement of blood 
levels of oestradiol in the present experiments, could be used as indirect evidence of an oestradiol surge following Gn-RH injections. Nevertheless ovulation did not always occur after an LH surge; it is possible that follicles in the post-partum cow after Gn-RH pulsing for 2-4 days can secrete sufficient oestradiol to cause an LH surge but are not sufficiently mature to ovulate, perhaps because the duration of treatment with $\mathrm{Gn}-\mathrm{RH}$ before the occurrence of an LH surge was not long enough. Alternatively, Gn-RH may have exerted a self-priming effect in the pituitary, which in turn gave rise to the LH surges without ovulation. The series of changes that occur in growth, concentrations of steroids in follicular fluid, and number of gonadotrophin receptors in follicles during the follicular phase of the oestrous cycle of the heifer have been documented (Ireland \& Roche, 1982) and similar data are required for follicular development in the post-partum cow to determine the correct dose regimen and duration of treatment with Gn-RH necessary to induce ovulation consistently in all cows. The role of FSH in follicular development in the anoestrous cow has not been elucidated and further work on this aspect is required. The present data suggest that multiple, low-dose injections of $\mathrm{Gn}-\mathrm{RH}$ can stimulate follicular development and maturation to the point of ovulation in some suckling beef cows. However, the responses to such regimens do not appear to be as consistent as those reported previously for anoestrous sheep (McLeod et al., 1982a, b), amenorrhoeic women (Leyendecker \& Wildt, 1983) or agonadotrophic rhesus monkeys (Knobil, 1980). The reasons for this discrepancy are unclear but may be related to the degree of follicular development at the onset of treatment, and the time of occurrence of an LH peak after pulsing.

We thank Mr D. Prendiville for expert technical assistance and Dr J. P. Gosling, U.C.G., Galway, Ireland, for the progesterone analyses.

\section{References}

Carruthers, T.D. \& Hafs, H.D. (1980) Suckling and fourtimes daily milking: influence on ovulation, estrus and serum LH, glucocorticoids and prolactin postpartum. J. Anim. Sci. 50, 919-925.

Casida, L.E., Graves, W.E., Hauser, E.R., Lauderdale, J.W., Reisen, J.W., Saiduddin, S. \& Tyler, W.J. (1968) Studies on the post-partum cow. Res. Bull. agric. Exp. Stn Univ. Wis. No. 270, 1-54.

Gosling, J.P., Parker, W. \& Fottrell, P.F. (1975) The routine operation of a radioimmunoassay for progesterone in bovine and ovine plasma. In Radioimmunoassay in Clinical Biochemistry, pp. 177-183. Ed. E. A. Pasternak. Heyden and Sons, London.

Greenwood, F.C., Hunter, W.M. \& Glover, J. (1963) The preparation of ${ }^{131} \mathrm{I}$-labelled human growth hormone of high specific radioactivity. Biochem. J. 89, 114123.

Humphrey, W.D., Kaltenbach, C.C., Dunn, T.G., Koritnik, D.R. \& Niswender, G.D. (1983) Characterization of hormonal patterns in the beef cow during postpartum anestrus. J. Anim. Sci. 56, 445-453.

Inskeep, W.K. \& Lishman, A.W. (1979) Factors affecting post-partum anestrus in beef cattle. In Beltsville Symposia in Agricultural Research. 3. Animal Reproduction, pp. 277-289. Eds H. W. Hawk, C. A. Kiddy \& H. C. Cecil. Albenheld-Osmun, Montclair, New Jersey.

Ireland, J.J. \& Roche, J.F. (1982) Development of antral follicles in cattle after prostaglandin induced luteolysis: changes in serum hormones, steroids in follicular fluid, and gonadotropin receptors. Endocrinology 111, 2077-2086.

Knobil, E. (1980) The neuroendocrine control of the menstrual cycle. Recent Prog. Horm. Res. 36, 53-58.

Knobil, E. (1981) Patterns of hypophysiotropic signals and gonadotropin secretion in the rhesus monkey. Biol. Reprod. 24, 44-49.

Leyendecker, G. \& Wildt, L. (1983) Induction of ovulation with chronic intermittent (pulsatile) administration of $\mathrm{Gn}-\mathrm{RH}$ in women with hypothalamic amenorrhoea. J. Reprod. Fert. 69, 397-409.

McLeod, B.J., Haresign, W. \& Lamming, G.E. (1982a) The induction of ovulation and luteal function in seasonally anoestrous ewes treated with small-dose multiple injections of Gn-RH. J. Reprod. Fert. 65, 215-221.

McLeod, B.J., Haresign, W. \& Lamming, G.E. (1982b) Response of seasonally anoestrous ewes to small-dose multiple injections of Gn-RH with and without progesterone pretreatment. J. Reprod. Fert. 65, 223230.

McNatty, K.P., Ball, K., Gibb, M., Hudson, N. \& Thurley, D.C. (1982) Induction of cyclic ovarian activity in seasonally anoestrous ewes with exogenous Gn-RH. J. Reprod. Fert. 64, 93-96.

Niswender, G.D., Reichert, L.E., Jr, Midgley, A.R., Jr. \& Nalbandov, A.V. (1969) Radioimmunoassay for bovine and ovine luteinizing hormone. Endocrinology 84, 1166-1173.

Oxenreider, S.L. (1968) Effects of suckling and ovarian function on post-partum reproductive activity in beef cows. Am. J. vet. Res. 29, 2099-2107.

Padmanabhan, V. \& Convey, E.M. (1978) Does time of exposure to estradiol and $\mathrm{LHRH}$ affect $\mathrm{LH}$ release from bovine pituitary cells? Proc. Soc. exp. Biol. Med. $159,157-160$. 
Padmanabhan, V., Kesner, J.S. \& Convey, E.M. (1978) Effects of estradiol on basal and LHRH-induced release of $\mathrm{LH}$ from bovine pituitary cells in culture. Biol. Reprod. 18, 608-613.

Peters, A.R. \& Riley, G.M. (1982) Milk progesterone profiles and factors affecting post-partum ovarian activity in beef cows. Anim. Prod. 34, 145-153.

Peters, A.R., Lamming, G.E. \& Fisher, M.W. (1981) A comparison of plasma LH concentrations in milked and suckling post-partum cows. J. Reprod. Fert. 62, 567-573.

Rahe, L.H., Owens, R.E., Fleeger, J.L., Newton, H.J. \& Harms, P.G. (1980) Patterns of plasma luteinizing hormone in the cyclic cow: dependence upon the period of the cycle. Endocrinology 107, 498-503.
Riley, G.M., Peters, A.R. \& Lamming, G.E. (1981) Induction of pulsatile LH release and ovulation in post-partum acyclic beef cows by repeated small doses of Gn-RH. J. Reprod. Fert. 63, 559-565.

Roche, J.F., Ireland, J.J. \& Mawhinney, S. (1981) Control and induction of ovulation in cattle. J. Reprod. Fert., Suppl. 30, 211-222.

Walters, D.L., Short, R.E., Convey, E.M., Staigmiller, R.B., Dunn, T.G. \& Kaltenbach, C.C. (1982) Pituitary and ovarian function in post-partum beef cows. III. Induction of estrus, ovulation and luteal function with intermittent small-dose injections of Gn-RH. Biol. Reprod. 26, 655-662.

Wiltbank, J.N. \& Cook, A.C. (1958) The comparative reproductive performance of nursed and milked cows. J. Anim. Sci. 17, 640-648.

Received 22 November 1982 